\title{
Newsreels, Documentary, Experimental Film, Shorts, and Animation
}

\author{
Josetxo Cerdán and Vicente Sánchez-Biosca
}

\author{
Introduction (Josetxo Cerdán)
}

This chapter focuses on key elements of Spanish cinema that lie outside the limits of the narrative feature film conceived for exhibition in commercial theaters. Its sections are intended as tasters to give an idea of certain features of newsreels, documentary, experimental film, shorts, and animation throughout Spanish cinema's long history. Two issues are singled out for separate treatment, since they are structurally central to the history not just of Spanish cinema but of Spain itself: non-fictional cinematic production during the Spanish Civil War (1936-9) and NO-DO, the state newsreel that the Franco dictatorship created in late 1942 and that continued to operate until 1981. The Civil War and NO-DO occupy the chapter's first two sections. We then pass to a methodological consideration of factors that need to be taken into account when considering alternative cinematic practices. The last part of the chapter proposes three conceptual axes for thinking about these alternative cinematic practices that go beyond genre or chronology while not abandoning either: the relations between center and margins, hybridization, and reflexivity.

\section{Non-Fiction Film during the Civil War (Vicente Sánchez-Biosca)}

\section{Newsreels and Documentaries}

After the resolutely avant-garde 1920s, the following decade saw the dramatic rise of the documentary format. The Depression, increased social tensions, and the 
rise of totalitarianisms and their all-out propaganda war were contributing factors. The fracture supposed by the Spanish Civil War was merely an acceleration of this tendency. The documentary field of the time was divided into two different rhetorical systems: the first resulting from the triumph of a new concept of "news" embodied in the newsreel; the second being propaganda and social critique, optimally expressed in documentary, which consequently took on a strong agitprop slant. There was no clear boundary between the two, but they obeyed recognizably different regimes of verisimilitude. In the former case, press correspondents, photographers, photo-journalists, and, of interest to us here, news cameramen mobilized to cover events "live." In the latter, dehumanization of the enemy, social confrontation, and the "brutalization of politics" became hallmarks of the propaganda documentary. Neither of these rhetorical systems was born with the Civil War. But, between 1936 and 1939 both faced a cleavage of international dimensions.

As the eye of the looming international storm, for three years Spain found itself traversed by newsreel crews from France, Germany, Italy, Britain, the USSR, and the United States, among other countries, who disseminated their images throughout the world (Alessandrini et al. 1999). To them we owe the configuration of an iconography of the Civil War that left indelible traces on the imaginary of the world war that followed (Sontag 2003). If the shots of air raids on Madrid or Bilbao-issued between 1936 and 1937 by the Soviet news agency Soiuzkinochronika for the newsreel series Events in Spain (Kowalsky 2003) - bear the stamp of the Soviet cameramen Roman Karmen and his assistant Boris Makaseev, the so-called "retreat" of the Republican Army and civilian population after the fall of Barcelona, in late January and early February 1939, was captured chiefly by the cameras of the French news agencies Gaumont Actualités, Pathé Journal, and Éclair Journal (Cadé 2010). While the overall mobilization was spectacular, the biggest single initiative was that of Fox Movietone News, which prided itself on showing only its own images; with up to fifteen film crews shooting throughout Spain, it became a vast visual arsenal (Romeiser 1991).

In practice, a fair proportion of these newsreel images, obeying criteria of verisimilitude appropriate to news journalism, were almost immediately put to propaganda use in documentaries: inflected though intellectual montage and subjected to agitprop voiceover, news became propaganda. A classic case is that of the footage taken in Madrid by Roman Karmen, using the "live report" method of filming. Edited and sonorized in Moscow, with strident voiceover and music, Karmen's images take on a certain heroic tone; borrowed or appropriated by dozens of propaganda documentaries, they express the pathos and anxiety of the civilian victims; when edited by Esther Shub, they generate a compilation film that is a brilliant example of montage: Ispaniia / Spain (Shub, 1939).

When we consider the production side of this documentary output, the frontiers between what is Spanish and what is foreign also frequently blur. Nationalist propaganda made more use of Nazi Germany than of Fascist Italy or Portugal. 
Berlin became its center of operations, both because of the rhetoric elaborated some years before by Goebbels' Ministry of Propaganda, which now took up the war in Spain as a central motif (Goebbels 1937), and because of the Geyer laboratories' material assistance. Decisive here was the figure of Joaquín Reig, who edited his films for the Falange (Spanish Fascist Party) in the German capital, and, after the creation of the Spanish-German production company Hispano-FilmProduktion in Autumn 1936 (see Chapter 2 and Chapter 14), participated in a series of effective anticommunist films that followed on from the company's first documentary production, Die Geissel der Welt / Scourge of the World (H. Weidemann, 1937): España heroica / Heroic Spain (1938) and its two German versions, Helden in Spanien / Heroes in Spain (1938 and 1939) (Nicolás Meseguer 2008). A more unusual anticommunist message is conveyed by the pro-Nationalist documentary Romancero marroqui / Der Stern von Tetuan / Tetuan Sky (Carlos Velo (uncredited) and Enrique Domínguez Rodiño, 1938-9), produced by the Spanish High Commission in Morocco, which presents Muslims and Christians as united by a common cause (Elena 2004). More complex, but not that different, is the relationship between Spanish and foreign initiatives in the case of pro-Republican documentary. Some of these productions were effectively independent, such as The Spanish Earth (Joris Ivens, 1937) undertaken by Contemporary Historians of New York. Others were solidarity initiatives of the political left, directly or indirectly indebted to popular-front agendas, such as Frontier Films' Heart of Spain (Herbert Kline and Geza Karpathi, 1937) and the films made by Henri CartierBresson (With the Abraham Lincoln Brigade, 1938, recently restored; L'Espagne vivra / Spain will Live, 1939; and Victoire de la vie / Triumph of Life, 1939). But the involvement of Spain's Ministry of Propaganda, created in November 1936 by the Socialist Francisco Largo Caballero, was fundamental to the gestation of Espagne 1936 / España leal en armas / Loyalist Spain at Arms (1937), conceived for overseas exhibition by Cine-Liberté together with the Spanish Embassy in Paris under Luis Araquistáin, and directed by the French Popular Front filmmaker Jean-Paul Le Chanois (Dreyfus) with the intervention of Luis Buñuel (Gubern and Hammond 2009: 303-17).

\section{Propaganda Models}

For many years, historians repeated the accepted notion that cinema produced in the Republican zone was rich, diverse, and vibrant whereas that of Nationalist Spain was the opposite: characterized by paranoid censorship and a glaring lack of imagination. This view is no longer sustainable. It is true that the first initiatives were on the Republican side and that the early months show a marked disproportion, partly due to the fact that the equipment, laboratories, and professionals were mainly in the territory under Republican control (Gubern 1986; Sala 1993). Nonetheless, with the exception of anarchist production, the propaganda models 
mobilized in Spain's war show the same features found in the Europe-wide propaganda war of the time, in terms of both motifs and formal properties: after all, anticommunism and antifascism were not a national matter (see SánchezBiosca 2006).

As mentioned, the surprising anomaly is the anarchist response to the military uprising, especially in Barcelona. The Anarchist trade union CNT (Confederación Nacional de Trabajo (National Labor Confederation)), which since 1930 had controlled the Sindicato Único de Espectáculos Públicos (SUEP; Single Public Entertainment Union) took over the Orphea and Trilla Studios (see Chapter 14) and, under the Office of Information and Propaganda directed by Jacinto Toryho, produced a considerable number of documentaries, among which the pioneering Reportaje del movimiento revolucionario en Barcelona / Report on the Revolutionary Movement in Barcelona (Mateo Santos, 1936) stands out. Its object was not the war, which had not yet started, but the social revolution that had taken over the Catalan capital in response to the military insurrection. By means of a "friendly" camera, involved in the events it is narrating, this on-the-spot report, lacking any sense of perspective, captured the libertarian rejoicing at the collectivizations, the taking over of the streets, the barricades, the opening of prisons, the burning of churches, and the departure of the first columns for the Aragonese front. These images would be a gift to the enemy, which almost immediately used them to denounce the chaos and destruction unleashed not by libertarian idealism but by communism (Sánchez-Biosca 2008-9). However, subsequent anarchist documentaries gave a highly novel angle on the war: in their desire to show the revolution, the series Aguiluchos de la FAI por tierras de Aragón / Eaglets of the FAI in the Fields of Aragón (1936) assembled images of daily life in the villages taken over by the FAI (Federación Anarquista Ibérica (Iberian Anarchist Federation)), reconstructions of battle scenes, and eulogies of its heroes (especially Durruti). In the same way, La toma de Siétamo / The Taking of Siétamo (Adrien Porchet, 1936) and La silla vacia / The Empty Chair (Valentín González, 1937) represent the particularities of this atypical war more successfully than the Madrid anarchists of the FRIEP (Federación Regional de la Industria de Espectáculos Públicos (Regional Federation of the Public Entertainment Industry)) were able to do in their series Estampas guerreras / Images of War (Armand Guerra, 1936).

Particularly efficient because of its speedy response, and crucial because of its length of operations, was the Commisariat de Propaganda de la Generalitat de Catalunya (Propaganda Commisariat of the Catalan Autonomous Government). In November 1936 it set up a cinema section, Laya Films, under Joan Castanyer. Equipped with two sets of sound-recording equipment, a production manager, an editor, six cameramen, a sound engineer, and assistants, from January 1937 it embarked on production of a weekly news report in Catalan, Espanya al dia / Spain Today, which it also issued in Castilian, English, and French. Closely connected to Laya Films was the production and distribution company Film Popular, created in Barcelona in fall 1936 and linked to the PCE-PSUC (Partido 
Comunista de España-Partit Socialista Unificat de Catalunya (Communist Party of Spain-Unified Socialist Party of Catalonia)). Indeed, Film Popular would issue the Castilian-language newsreel España al dia jointly with Laya Films from March 1937 until the fall of Catalonia to the Nationalists; its content and commentary differed from those of the Catalan version. Also significant among productions linked to Marxist organizations was Defensa de Madrid / Defense of Madrid (Ángel Villatoro, 1936), made by the International Red Cross in collaboration with the Alliance of Anti-Fascist Intellectuals.

Nationalist production was faced with a very different situation. With the exception of the Falange, none of the sectors grouped under the Nationalist umbrella had a concept of propaganda. Neither CIFESA (responsible for around twenty documentaries) nor CEA, the two companies responsible for the first Nationalist films, showed themselves to have an adequate grasp of the needs of the moment. Neither did the military authorities feel any desire to entrust propaganda to political hands. It was the documentary production of the Falange's Film Section that would forge an iconography seen simultaneously in the illustrated magazines Fotos, Vertice, and Y, among others. Its films Alma y nervio de España / Soul and Sinew of Spain (J. Martínez Arboleya, 1937), Frente de Vizcaya y el 18 de julio / Vizcaya Front and the 18th July (1937), and Los conquistadores del Norte / Conquerors of the North (1937) display features that would remain constants of Nationalist film propaganda: newsreel-style voiceover, ceremonies commemorating the dead, and a rhetorical mode of locution. Frente de Vizcaya includes the first example of counterpropaganda relating to Guernica. If we compare this film to España heroica, we can see the innovation introduced by Berlin: the reappropriation and re-editing of enemy material, which would be a basic feature of later Francoist propaganda.

With the establishment of the first Francoist government in late January 1938 and the reorganization of the Press and Propaganda Services within its Interior Ministry (headed by Franco’s brother-in-law, the lawyer Ramón Serrano Suñer), the Departamento Nacional de Cinematografía (DNC; National Cinema Department) was created the following April, under the direction of the poet, former member of the Foreign Legion, and journalist Manuel Augusto García Viñolas. The dynamism of the DNC's propaganda effort made an immediate impact. In coordination with the Nationalists' other propaganda instruments (radio, press, magazines) in a project that the first Nationalist Head of Propaganda, Dionisio Ridruejo, would describe as "totalitarian" (1976: 130), the newsreel Noticiario Español was issued from June 1938, together with a series of documentaries that illustrate the key components of Nationalist propaganda: the treatment of prisoners (Prisioneros de guerra / Prisoners of War, García Viñolas, 1938); denunciation of Communist repression and torture (Vivan los hombres libres / Long Live Free Men, Edgar Neville, 1939); the cult of the dead in the person of Falange's founder, José Antonio Primo de Rivera, executed in Alicante prison on November 20, 1936 (iPresente!, 1939); some war reports (disappointing compared to the 
Republican material); parades, celebrations, and triumphal tours by the Caudillo (El gran desfile de la victoria en Madrid / The Great Victory Parade in Madrid, 1939; Viaje triunfal del Caudillo por Andalucia / The Caudillo's Triumphal Tour of Andalusia, 1939); and activities of organizations charged with indoctrinating the population (Juventudes de España, Edgard Neville, 1939; La concentración de la Sección Femenina en Medina del Campo, 1939) (Tranche and Sánchez-Biosca 2011: 491-6).

In sum, in the light of recent studies we can conclude the following: first, that the international dimension of the Civil War makes it impossible to treat national and foreign production separately; second, that it is necessary to consider the always shifting relationship between the regime of verisimilitude corresponding to news journalism, as in the live coverage of photo-reportage and newsreels, and that corresponding to powerful propaganda machines; and, finally, that it is necessary to examine documentary production on the Nationalist side without prejudice or blinkers, situating it on the same level as anticommunist production of the period elsewhere.

\section{NO-DO: The Francoist Newsreel (Vicente Sánchez-Biosca)}

On January 4, 1943, the first Spanish cinemas opened their program with a ten-minute newsreel covering what the Franco regime - locked in the grip of World War II (non-belligerent but explicitly pro-Axis) - regarded as "national news." The newsreel was preceded by a prologue that served as a mission statement (see Figure 18.1). Although it was not conceived as a purely short-term instrument, its duration - until 1981, when cinema newsreels were a distant memory - exceeded all expectations. The machinery had been set in motion some months before. An agreement dated September 29, 1942 of the Vicesecretaría de Educación Popular de FET y de las JONS (Vice-Secretariat for Popular Education of the FET y de las JONS (the official title of the political grouping resulting from Franco's forced merger of the fascist Falange with the traditionalist Carlists in 1937)) had set out the guidelines for the organization and operation of the Noticiarios y Documentales (Newsreels and Documentaries; NO-DO for short). A December 17, 1942 disposition of the same Vice-Secretariat announced its monopoly over newsreel production and the requirement that its news bulletins be screened in all Spanish cinemas. It was, then, a fast, energetic start, and, four months later, with its twentieth bulletin, NO-DO would inaugurate a second edition. This and the privilege of being the only institution allowed to produce newsreels in Spain make it clear that NO-DO's arsenal of images was, especially before television became widely available in the course of the 1960s, the almost exclusive source of documentary footage for public consumption under Francoism and its most efficient audiovisual instrument of socialization (Tranche and Sánchez-Biosca 2000) (see Figure 18.2). 


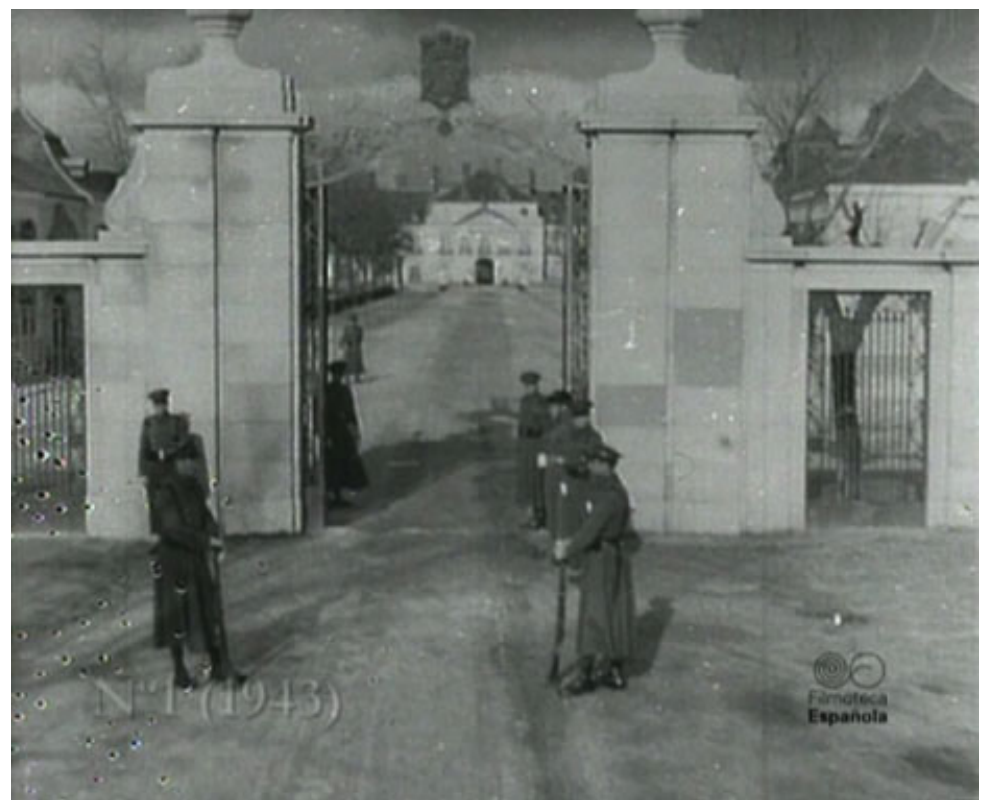

Figure 18.1 NO-DO's camera enters Franco's residence at the Palacio del Pardo: prologue to the first NO-DO (4 January 1943). Courtesy of Filmoteca Española.

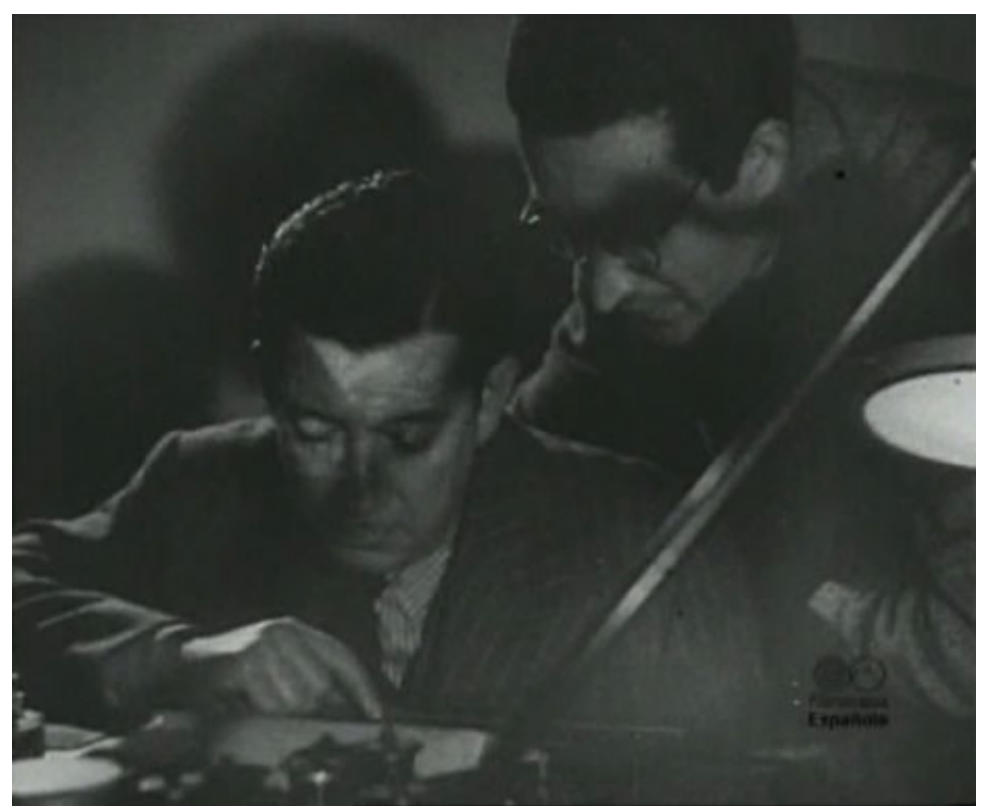

Figure 18.2 Behind the scenes at NO-DO: Joaquín Soriano (director) and Alberto Reig (assistant director) on the moviola (NO-DO 105 A, 1945). Courtesy of Filmoteca Española. 


\section{Paradoxes}

One inevitably has to start by considering NO-DO as a propaganda instrument, as were the other media of the time (press, radio, cinema). All the fundamental values of Francoism appear in its images; the regime's institutions loom large and proud in its news coverage and reports; the enemy is lambasted and refuted acrimoniously in its voiceovers; and the professionals responsible for its making rarely had brushes with their superiors. Nonetheless, the term "propaganda" proves inadequate as a way of understanding the newsreel's logic and, while not untrue, is more confusing than enlightening. Effectively, what needs to be examined is NO-DO's time lag with respect to front-line propaganda of the interwar period - a time lag that chronologically is slight but in stylistic and rhetorical terms is fundamental.

NO-DO's first paradox is that it represented a tenacious effort, unheard-of in a news medium, to avoid "news" and to sideline political information. The historian trawls its images in vain for precise details about national or even international events. The ideological warfare in which it unsurprisingly engaged did not take place on the terrain of current affairs. Considering that it was made in a country that was highly ideologized, close to other European fascisms, and with an iron control over communications, NO-DO is positively laconic. Its omissions, absences, even frivolity leave the researcher perplexed - curiosities, amusements, social functions, fashion, nature, sport, bullfighting, and natural disasters take on an importance not found in other newsreels. In practice, NO-DO would not cease, in its most ideologized sections, to remind viewers of the "crusade" (as the regime termed the Civil War), lingering over ceremonies to honor the "fallen" (on the Nationalist side) or over the regime's sites of memory, and taking viewers round the schools of Sección Femenina (Women's Section of the Falange) or the camps of the Frente de Juventudes (Youth Front), immersing viewers in an unequivocal symbolic repertoire. And yet, its lack of dramatic tension, the primacy given to the secondary, and omission of the political would be its immediately distinctive traits.

This is better understood if we consider the political conjuncture from which NO-DO was born in 1942-3. After a period of Falangist hegemony in documentary film production (1938-41), the team led by Serrano Suñer fell in the cabinet reshuffle of May 1941, with Press and Propaganda Services moving from the Interior Ministry to the recently created Vice-Secretariat of Popular Education. After the Falangist bombings at Begoña (Bilbao) on August 16, 1942, Serrano was definitively relegated, the totalitarian dream collapsing with him. The international context of World War II must also be taken into account. When NO-DO was launched in January 1943, the likelihood of German victory on the Eastern front was already in question, and indeed Marshal von Paulus surrendered at Stalingrad on February 2. That produced a climate of uncertainty that made advisable a more cautious position on Spain's part, which in October 1943 translated into abandonment of the policy of non-belligerence for a return to neutrality. 
After unconditional victory in the Civil War and the ensuing repression and extermination of the enemy, as the regime took on an increasingly conservative slant and the most revolutionary sectors of the Falange were disbanded, and with the prospect of Allied victory exposing Spain to reprisals, the propaganda project that ended up imposing itself was one of encouraging acceptance of Francoism rather than one of political agitation. It was a matter not of mobilizing the masses but of demobilizing them, while maintaining the display of religious, political, and charismatic symbols together with a formal, figurative rhetoric that had been supplied by the Falange (and, to a lesser extent, by the Carlists and a baroque-inspired Catholic liturgy). NO-DO was born at a moment when the regime was repositioning itself, backing off (apart from some significant moments) from the confrontational stance of previous years.

Two further factors define the newsreel. Unlike the radio and press, NO-DO had no ideological diversity, no rough edges. While the differences (even of tone) between the monarchist, Falangist, war veterans', and Church press provide the historian with substantial insights into the frictions and dynamics of the koine that was Francoism, NO-DO, by contrast, operated as the regime's sole newsreel, with no signs of ideological in-fighting. Thus, NO-DO spoke as the regime's single, standardized voice, free of fissures and conflicts, Francoism's doxa. A practical circumstance reinforced its atemporal sameness: the lack of exhibition copies. The more lowly the category of cinema, the older the newsreels shown, producing the comic situation, noted as late as 1952 by NO-DO's deputy director, that at Christmas some cinemas screened the news corresponding to the same time last year. In sum, everything favored the lack of topicality, with preference given to what we might call "news of the period" (the longue durée) rather than "the latest news."

\section{Document and Ritual}

To appreciate the role played by NO-DO in Francoism's first decades, it is necessary to understand the period's visual climate and expectations about access to information: a single audiovisual news medium; isolation from the outside world; little familiarity with the culture of travel; curiosity about the exotic. With no television and homes equipped only with radio sets that, by definition, were limited to sound commentary, censorship was all-pervasive; enforced silence sealed the lips of those who had avoided exile, prison, or execution; and the institutions of socialization and indoctrination operated at the microlevel of the village or neighborhood, workplace, school, or parish. In this context, NO-DO had a hugely powerful role to play: that of providing Spaniards with knowledge of a previously codified reality in a visually attractive manner.

As one of Francoism's instruments of socialization, NO-DO was responsible for creating what is ambiguously called "sociological Francoism," though its success in this respect is hard to measure. But what does a newsreel document when it 
avoids "news" but for the most part does not engage in direct propaganda either? This is a key question. NO-DO's inertia reflects the regime's creative apathy. The newsreel's images plunge the spectator into a world that seems not to move: immune to change, always identical to itself, subject to perpetual ceremonial albeit dotted with exotic and curious trivia. Its succession of ritual commemorations followed an immovable calendar: April 1, with its celebration of Nationalist victory and the military parade at its center; May 1, with the parades of the single state-controlled union; April 18, with its exaltation of work, its inaugurations, and the inevitable reception of the diplomatic corps; October 29, a day of mourning, and even more so November 20, the day of remembrance of the death of José Antonio, buried in the Escorial and in 1959 moved to the Valle de los Caídos (Valley of the Fallen). These date markers combined with others of lesser ideological intensity to conjugate the calendar year: Christmas, imbued with the melancholy, kitsch mood that Francoism bestowed on it; Epiphany, with its stilted infantile chants addressed to the Reyes Magos (the Three Kings, Spain's equivalent of Santa Claus); the "profound Spanishness" of Holy Week, austere in Castile, tragic in Andalusia; plus those local fiestas that merited remembrance in the "national interest." With these ingredients, NO-DO stitched together a hermetically sealed, atemporal circle. Time, in the sense of change and the singular event, disappeared. In its place was ritual, the memory of another time of plenitude and intensity that Francoism yearned for.

Few documents match NO-DO's capacity to represent the Franco regime's ritualistic basis: decisive historical events were replaced by static commemoration, as if the last heroic gesture (the Civil War, the "crusade") had exhausted energies and suspended the country in a dream of plenitude (national, imperial, religious) such that nothing else could ever happen - a historical mirage but also an arrest of history. This spectral dimension of time would be overlaid by the proliferation of symbolically overcharged spaces, the expression in spatial terms of this same ritualism. Three of these stand out - the Valle de los Caídos, the monumental mausoleum dreamed up by Franco as a burial place for the victims (especially on the Nationalist side) in the Civil War; the Toledo Alcázar, where Colonel Moscardó held out against the republican siege in the summer of 1936; and the Escorial, built on Philip II's orders as an embodiment of the spirit of the Counter-Reformation, which would inspire Francoism - though one could add others, such as the Ciudad Universitaria, Paracuellos de Jarama, or Cerro de los Ángeles. This list should suffice to give a clear idea of the Francoist conception of time and space, which NO-DO translated into images.

To conclude, through its representation of time and space, NO-DO became the weekly ritual of a ritualistic, ceremonial state; repetitive ad nauseam, indifferent to change. The more it repeats itself and the more echoes it generates with its unchanging annual liturgy, the more it tells us about the model of society that the regime wished to impose: static, acclamatory, but socially and politically deactivated. This sensation comes over especially strongly to today's historian, attentive 
to the symbolic significance of décor and place, scenography and verbal rhetoric. NO-DO's message hits the cultural historian in the face.

\title{
Change, Finally
}

Ritualism is necessarily bound up in an intense dialectical relationship with the pressure of change, and NO-DO underwent a major upheaval in the course of the 1960s. The rhetoric of Francoist motifs (its sites of memory and liturgical calendar) did not disappear, but it had to face the emergence of a parallel rhetoric that either tacitly contradicted it or took over its spaces, testifying to their transformation. The language of development was a new rhetorical regime based on the incontestable authority of numbers and calculations, technocratic, often opaque, and apparently deideologized. This discourse coexisted with the previous one in accordance with Francoism's facility for co-opting incompatible linguistic practices, mixing those derived from its military origins with others relating to its more recent legitimization through its achievements (peace, prosperity, work). NO-DO underwent this curious metamorphosis through its relationship to television, for some years in tandem and collaboration (the highpoint was perhaps the 1964 commemoration of the "25 Years of Peace"), but in 1968 it was absorbed into the Dirección General de Radiodifusión y Televisión (Directorate General of Radio and Television). This allowed the news of tourism and economic development to coexist alongside the sites of memory and commemorations of the past, in a syncretism that at some times was masterly and at others bordered on the ludicrous. NO-DO's use of language, defiance of logic, and stubborn persistence in the use of certain symbols speak volumes of Francoism. That is NO-DO's documentary value - as a cultural document.

\section{Shorts, Documentary, Experimental Film, and Animation in Transhistorical Perspective (Josetxo Cerdán)}

\author{
Historical Change
}

At the end of 2007, the Academia de las Artes y las Ciencias Cinematográficas de España (Spanish Film Academy), which gives the Goya awards (Spain's equivalent of the Oscars), announced publicly that it was planning to eliminate from the gala ceremony the handing over of its three awards for Best Short (in the categories of animation, documentary, and fiction). Spanish short directors were quick to respond and showed an impressive capacity for mobilization; as a result, the Academy was forced to back down. This incident illustrates the weight that directors of short films have acquired, as a collective, in twenty-first-century Spain. 
At no earlier point of time can we talk of an organized collective of short filmmakers able to make a public impact.

This raises a fundamental question: although the term "short" (cortometraje) is used generically to refer to a body of films lasting less than thirty minutes, the social, cultural, and indeed formal value attached to such productions has varied hugely at different historical moments. The term "short" can be used to refer to Una de fieras / Wild Animal Movie (Eduardo García Maroto, 1934), Verbena / Carnival (Edgar Neville, 1942), Pompurrutas imperiales / Imperial Jingles (Fernando Colomo, 1976), Mirindas asesinas / Killer Mirindas (Álex de la Iglesia, 1991), and 7:35 de la mañana / 7:35 a.m. (Nacho Vigalondo, 2003), but the different historical circumstances in which these various films originated make them very different cinematic exercises. They do not even all share the common denominator usually attributed to shorts (questioned by some short filmmakers): that of being "trampoline" films helping young directors to establish themselves in the field and to go on to make full-length features. Neville had already directed several feature films when he accepted Saturnino Ulargui's invitation to make Verbena in 1942, and, as the above anecdote implies, in the last decade one can talk of short filmmaking as an established field in its own right. Indeed, Vigalondo's aim when he made 7:35 de la mañana was not to establish himself as a feature filmmaker but to be nominated for an Oscar for Best Fiction Short. Six years later, Javier Recio also got an Oscar nomination, this time for Best Animation Short, with La dama y la muerte / Death and the Lady (2009).

Thus, we can call all these films "shorts" but the different historical conditions under which they were shot make them very different cinematic objects. Recio's and Vigalondo's films share the same codes of production, circulation, and consumption, which set them apart from the earlier films listed above. For, since the late 1990s, Spanish shorts have entered a phase marked by the decentralization of production subsidies, with the production and dissemination of shorts becoming a way in which the autonomous communities can promote their image and "brand." The first to do this was the Basque Country, which set up Kimuak to turn the short into the flagship defining a concept of Basque cinema from 1998 onward (see Chapter 4). Other autonomous communities followed suit with similar initiatives. Thus, for the first time in history, there are structures for the production and dissemination of shorts outside the historical centers of production in Madrid, Barcelona, and Valencia. This has two immediate consequences: the production of shorts as a means of self-promotion for new directors has shifted to digital format and dissemination via the Internet (www.notodofilmfest.com/\#/Home) and specialist distributors for shorts have sprung up (e.g., Lolita peliculitas). While we are still talking about "shorts," this has nothing to do with shorts as they were conceived in earlier periods.

The same need to distinguish between production in different periods arises when we consider animation, documentary, or experimental cinema. The first full-length animation film made in Spain - Garbancito de la Mancha (Arturo Moreno, 1945), scripted by the Falangist Julián Pemartín and made in the middle of the 
period of autarky (isolation and economic self-sufficiency) after the Civil War had a clear propaganda message aimed at a public cut off from the outside world. At the other historical extreme, Planet 51 (Jorge Blanco, Javier Abad, and Marcos Martínez, 2009) was the first Spanish animation film made with a transnational exhibition plan allowing it to be released in over thirty countries, distributed in the United States by TriStar (for theaters) and Sony Pictures Home Entertainment (for home-entertainment formats).

With regard to documentary production (leaving aside newsreels): in the 1920s and 1930s it had a fundamentally propagandistic function, often relating to national identity politics, including from at least the late 1920s that of Spain's historical nationalities. In the course of the Franco dictatorship, in a very small number of productions made outside the framework of NO-DO - for example, Juguetes rotos / Broken Toys (Manuel Summers, 1966) - documentary started to take on new forms. Not surprisingly, the flood of documentary production in the 1970s obeyed a strong political impulse, but in many cases these films would be very different formally from the traditional propaganda film. El desencanto / The Disenchantment (Jaime Chávarri, 1976), La vieja memoria / The Old Memory (Jaime Camino, 1977), Raza, el espiritu de Franco / Race, the Spirit of Franco (Gonzalo Herralde, 1977), and Ocaña, retrat intermitent / Ocaña, an Intermittent Portrait (Ventura Pons, 1978) are four films that settle accounts with the dictatorship in different ways, but they do so with no intention of indoctrinating the spectator (see Català et al. 2001).

In the case of experimental cinema, the historical discontinuity is total. If we consider its beginnings, critics are still divided over whether films such as $E l$ sexto sentido / The Sixth Sense (Nemesio M. Sobrevila, 1929) are avant-garde or antiavant-garde, while Luis Buñuel's first two films - Un chien andalou (1929) and L'Âge d'or (1930) - are French. It was only in 1930 that two works by the Falangist writer and cultural entrepreneur Ernesto Giménez Caballero - Noticiario del cineclub / Film Club News and Esencia de verbena / Essence of Carnival - would acclimatize experimental cinema in Spain. These experiments - which Giménez Caballero arranged to have screened abroad (Gubern 1999: 442-3) - have a closer relationship to certain works by Catalan amateur filmmakers of the time (e.g., Delmiro de Caralt or Domènech Giménez) than to the experimental films made by certain Spanish artists from the 1950s on, such as Aguaespejo granadino / Granada Water Mirror (José Val del Omar, 1955; see below) or Operación H / Operation H (Néstor Bastarretxea, 1963).

It is therefore crucial to consider how the production models and formal properties of shorts, animation, documentary, and experimental film have changed over time, rather than making generalizations about them as a series of discrete cinematic forms. Even more important is the need to consider the different ways in which, at different historical moments, they have been circulated, viewed, and consumed by their various audiences. The following sections will consider these cinematic forms in terms of a series of transhistorical conceptual axes, but in each case will take historical factors into account. 


\section{The Centrality of the Marginal}

At least two historical factors have to be borne in mind in order to understand the particular relationship in Spanish cinema between mainstream industrial production (centered on narrative feature films) and production taking place on the industry's margins (shorts, documentary, experimental film, animation). First of all, Spain's incorporation into the industrial revolution and modernity was late and achieved at high cost. A backward country in terms of all the criteria used to measure development in the late nineteenth century, this became notoriously evident with the loss in 1898 of Spain's last significant colonies in a war with the technologically more advanced United States. In these conditions of backwardness and general demoralization, the introduction of a modern form of entertainment such as the cinematograph was bound to be difficult. Second, we should remember that the outcomes of the Spanish Civil War and of World War II conflicts that were in many respects intimately related, with a gap of only a few months between them - were diametrically opposed. While the end of World War II meant the defeat of fascism in Western Europe and the adoption of liberal democratic models, in Spain Franco's victory led to an autarkic dictatorship that imposed a politics of revenge, extermination, and pillage, with many forced into exile. Only with the passage of time, chiefly to ensure the regime's survival, were certain minimum social and economic freedoms permitted, always under police surveillance and subject to suppression at any moment. Almost forty years of Francoism made an indelible mark, not only on the development of the film industry but also on the possibility of developing alternative cinematic practices on its margins.

Given the first of these factors, it is hardly surprising that, as Pérez Perucha has observed (1993), during the whole period of silent cinema in Spain, production companies, economically precarious and with limited possibilities of commercial exploitation in the national market, were forced to channel their efforts into producing panoramas (a distant cinematic antecedent of the documentary film) and newsreels instead of fiction films, since the latter required more resources (lighting in order to shoot interiors, the hire of actors and scriptwriters, etc.). The producers of Spain's fledgling cinema were economically dependent on their ability to sell their newsreels, panoramas, and other pre-documentary material abroad. It is important to note that the great figures of early Spanish cinema also operated in these marginal areas. The first Spanish filmmaker to acquire an international name was Segundo de Chomón, who did so thanks to his mastery of techniques linked to animation, such as superimposition, hand coloring, and frame-by-frame shooting. His skills were recognized when Pathé contracted him in 1906 to work in France, where he would make some of his best-known films, such as El hotel eléctrico / The Electric Hotel (1906) (Minguet Batllori 2010). The other outstanding figure of the silent period is Buñel, who made his name in experimental film with Un chien 
andalou and L'Âge d'or - both filmed in France, though the first was financed with money from Spain and the second contains a few scenes shot on the Costa Brava. Both films brought Buñuel recognition in Paris avant-garde circles of the late 1920s. When Buñuel made his first film in Spain, it would be a propaganda documentary: Las Hurdes / Land without Bread (1933). While Spanish silent cinema had a prolonged dependence on newsreels, panoramas, and other pre-documentary material, and its most remarkable creators were a precocious pioneer of animation (Chomón) and a central figure in the avant-garde (Buñuel), narrative fiction film produced in Spain barely reached national audiences until virtually the end of the 1920s.

This centrality of the margins is found again at other moments. During the late Franco period, when to make a film one first had to obtain a shooting permit (i.e., get the censor's approval), a significant number of filmmakers decided to work "illegally" on the industry's margins, creating an oppositional cinematic corpus that, although unseen in commercial theaters, took on great importance in alternative exhibition circuits. Perhaps the figure who best exemplifies this move from professional to underground filmmaking is Basilio Martín Patino, who saw his Canciones para después de una guerra / Songs for After a War banned (made in 1971, it would not be screened until 1976) and decided to go underground, making two more unauthorized documentaries before the dictator's death in 1975: Queridisimos verdugos / Dearest Executioners (1973) and Caudillo (1974). These underground filmmakers had varied profiles: from the documentary filmmaker Helena Lumbreras, linked to the Communist Party, who made militant films (El campo para el hombre / The Land for Men, 1973) to an iconoclast like Antoni Padrós (Lock Out, 1973; Shirley Temple Story, 1976). The underground film movement took on such importance that in 1974 a distribution company was created for this kind of work, La Central del Curt, which contined to operate until 1981.

With cinema converted into a digital industry in the twenty-first century, few production companies operating in Spain make only narrative feature films for the big screen: first, because significant holdings in production companies are held by media and pressure groups who oblige them to diversify production; and, second, because cinema is now part of a much broader audiovisual system that includes the production of content for television, the Internet, or institutions of every kind. In this new audiovisual universe, transnational and yet atomized, Spanish cinema continues to occupy certain niches that permit the creation of "anomalous" projects that, on occasion, impact on the industry's center. This is the case with, for example, two animated features films made in the last decade: Un perro llamado Dolor / A Dog called Pain (by the singer and painter Luis Eduardo Aute, 2001) and De profundis (by the graphic novel artist Miguelanxo Prado, 2006; see Chapter 4) both formally eccentric in their balancing of industrial and artisanal production. A similar eccentric position is occupied by the experimental films of Albert Serra (Honor de cavalleria / Quixotic, 2006) and the documentaries of Óscar Pérez (El sastre / The Tailor, 2007): produced on the industry's margins, these films have garnered considerable accolades and won awards at some of the most prestigious 


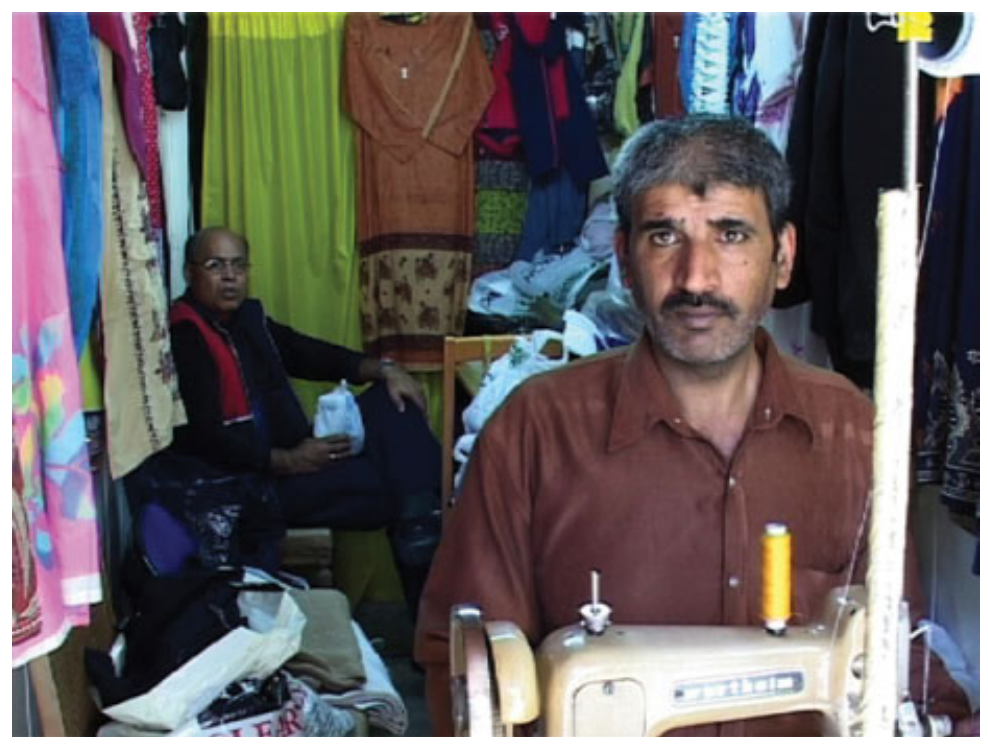

Figure 18.3 El sastre (2007) - directed, shot, edited, and produced by Óscar Pérez - won the Best Short Documentary Film award at the Amsterdam International Documentary Film Festival. Courtesy of Óscar Pérez.

international festivals, achieving a global recognition rarely attained by mainstream Spanish cinema (see Figure 18.3).

\section{Hybridization}

There is no doubt that, throughout the history of cinema, the border between animation and experimental film, and between the latter and documentary, has been highly porous. Already in the 1920s, visual music and urban symphonies illustrated these two kinds of hybridization. In the case of an underdeveloped film industry such as that of Spain, these mixtures have possibly occurred even more frequently. This is not just because their creators had an interest in innovation but also because, lacking a well-established tradition, they found themselves operating on shifting terrain. In this respect, it is not surprising that many figures have occupied different roles in one or other of these fields. In current times, Begona Vicario is a clear example of this mobility. She started out directing and producing her experimental animation work in the mid-1990s - her best-known piece is Pregunta por mi / Ask after Me (1996). Then she wrote Breve historia del cine de animación experimental vasco (Short History of Basque Experimental Animation, 1998), which sketches the work of ten key figures, including herself. Later, she appeared as producer for a film by another female experimental animation director, Hezurbeltzak / A Common Grave (Izibene Oñederra, 2007). The low level of professionalization 
encourages a proliferation of hybrid products; conversely, moving around different roles within the creative community can help to achieve professionalization - thus, Vicario can promote the field to which she contributes creatively as director by also operating as critic or producer. This hybridization process should not be seen as a limitation; on the contrary, it pushes boundaries in all three of these marginal fields: experimental film, documentary, and animation. Additionally, the practice of moving between production, direction, and even criticism helps to create a sense of community.

Six decades before Vicario, José Val del Omar had already cultivated the hybridization of documentary and avant-garde in the 1930s (Vibración de Granada / Granada Vibration, 1935). Two decades later, opting resolutely for technical experimentation, he would add to that mix elements more usually associated with animation, with his two most important works: Aguaespejo granadino (1955) and Fuego en Castilla / Fire in Castile (1960). Both fuse technical and formal experimentation with a documentary focus on Andalusia and Castile that oscillates between myth and ethnography. Also during the Republic, Carlos Velo introduced into his documentary film projects some of the innovations of Soviet avant-garde cinema of the previous decade.

In the 1960s, some of the figures associated with the Barcelona School (see Chapter 3) would make a series of interventions in documentary film with a clear experimental vocation. Three very different examples are Lejos de los árboles / Far from the Trees (Jacinto Esteva, 1970), El sopar / The Dinner (Pere Portabella, 1974), and Numax presenta ... / Numax presents ... (Joaquín Jordà, 1980). Portabella expanded into collaborations that went beyond the cinematic, working with artists in various media: music (Playback, 1970) with Carles Santos, painting (Miró l'altre / The Other Miró, 1969) with Joan Miró, and poetry (Lectura Brossa / Brossa Reading, 2003) with Joan Brossa (see Chapter 3 and Chapter 6). This cross-fertilization between cinema and other arts had been anticipated by the first experiments with visual music on the part of Equipo 57, a collective of Spanish artists founded in Paris in 1957, though perhaps the most remarkable experiment of this kind was Ere erera baleibu icik subua arauren (José Antonio Sistiaga, 1970; the title is Basquesounding nonsense language), a full-length seventy-five-minute film consisting entirely of hand-painted celluloid.

At the opposite end of the spectrum, in the 1960s animation also joined hands with fiction feature film in some interesting hybrid products. What made this possible was animation's professionalization in the field of advertising, especially thanks to television. The chief contribution of animators here was the creation of credit sequences, but in some cases it was more extensive - for example, in José María Forqués 1968 film featuring the rock group Los Bravos, Dame un poco de amooor ...! / Bring a Little Loving, whose pop-inspired animations were created by Francisco Macián.

Iván Zulueta's work must be included in any discussion of animation and experimentalism (see Chapter 21). Zulueta's experimental films made in Super 


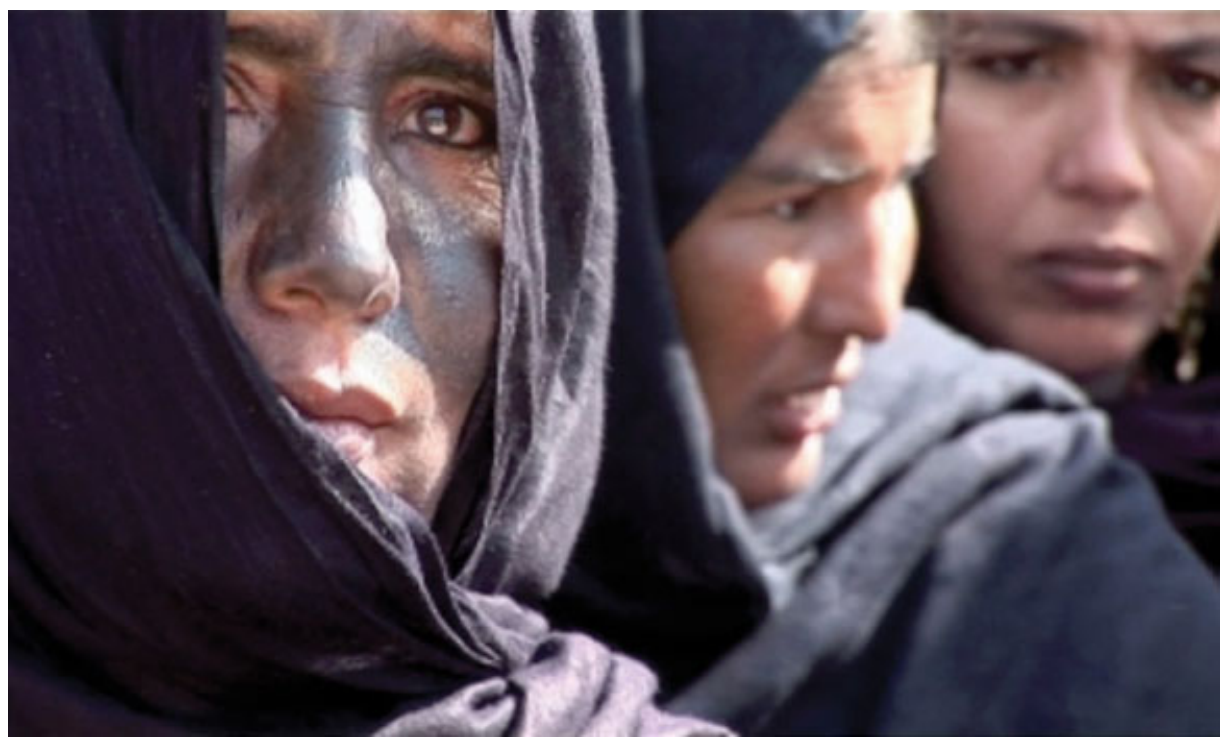

Figure 18.4 Tuareg women protect themselves from the sun in the desert, captured with an intense realism by Lluís Escartín's camera in Amanar Tamasheq (2010, prod. Lluis Escartín / Green Valley). Courtesy of Lluis Escartín.

8 and $16 \mathrm{~mm}$, with their extraordinary plasticity, incorporate a whole repertoire of trick photography associated with animation - though perhaps his most outstanding works in this field are those made for television. During the two seasons when he was responsible for the youth program Último grito / The Latest Craze (1968-70), he used various animation techniques to make pop songs of the time come alive. Nonetheless, Zulueta's major work is beyond doubt Arrebato / Rapture (1980), a fiction film produced within a relatively normal industrial framework, appealing to the generic features of horror film but with a plotline that allowed him to introduce fragments from his earlier experimental shorts, making the film a hybrid mix of genre film and experimental film.

Finally, it should be noted that the irruption of digital systems into cinema in the 1990s has produced a new convergence between cinema and art at an institutional level. In Spain this process is very evident in what is known as experimental documentary. Works such as those of Virginia García del Pino have found funding from art institutions but are released at film festivals. The work of María Cañas is as likely to be shown in an art gallery as in a touring film series. Andrés Duque has been nominated for Goya awards, but his works are shown in exhibition spaces such as La Casa Encendida and MNCARS (Museo Nacional Centro de Arte Reina Sofía). Lluís Escartín won the prize for Best Short with his film Amanar Tamasheq (2010) at the international documentary film festival Punto de Vista, but his work is deposited in the video library of the Fundació La Caixa (see Figure 18.4). Isaki Lacuesta alternates between fiction films for exhibition in commercial theaters 
(e.g., Los condenados / The Condemned, 2009) and very different joint projects with the filmmaker Naomi Kawase, the novelist and theater critic Marcos Ordóñez, or the painter Miquel Barceló. All these filmmakers share a common mobility and capacity for hybridization. That perhaps does not make them a "generation," but they comprise the first group of Spanish creators who see their work as occupying a hybrid space somewhere in between cinema and the museum, both formally and in terms of production and exhibition.

\section{Reflexivity}

One of the obsessions of Spanish critics writing about Spanish cinema has been the issue of "realism." This dates back to the initial attempts at constructing a national cinema in the late 1920s, which set up an opposition between the españolada (stereotypical representation of Spain) and a cinema that would depict Spain as it "really" was; that is, an opposition between the artificial and the genuinely Spanish. This was reactivated after the Civil War by Francoism, which equated realism with its own discourse (initially Falangist, later National-Catholic) on the essence of Spain. The topos took on new life with the impact on Spain of Italian neo-realism and the European New Waves. And it has been revived recently by critics who reject the "postmodernity" of Spanish cinema as a sign of its disconnect from the country's reality. It is striking that there have been few critical texts devoted to the reflexive side of Spanish cinema, when this has been an evident feature throughout its history (Castro de Paz and Cerdán 2007). Reflexivity is understood here in the sense given to the term by Robert Stam (1992) as a "different tradition" from that of realism - one that formally highlights the process of textual construction. Stam's key examples are taken from Spanish culture: Cervantes, Velázquez, Goya.

This reflexivity, as widespread as it is understudied, is even more marked, if such a thing is possible, in those cinematic forms on the industry's margins - for example, it has been claimed as a characteristic of Brazilian cinema (Vieira 1982). There is no need to insist on the reflexivity of Spanish experimental cinema, since experimentalism by definition involves reflexivity. But attention does need to be called to the reflexivity of shorts, since this is where it is most evident, especially in periods when cinematic models have tended, through various strategies of erasure, to hide their enunciative mechanisms. Early works such as the already mentioned El sexto sentido or Edgar Neville's Yo quiero que me lleven a Hollywood / Take Me to Hollywood (1931), a film that revolves around the mechanics of stardom, are clear examples of this reflexivity. But it is even more striking in the series of three shorts - Una de fieras / Wild Animal Movie; Una de miedo / Scary Movie; Y, ahora, una de ladrones / And Now a Gangster Movie - made by Eduardo García Maroto between 1934 and 1936, which parody successful film genres of the time. The first, Una de fieras, starts by showing a three-thousand-peseta check - the money raised to make the film - and continues with images of the film crew together with the actors, a selection of the 
settings to be used, and so on; in a nutshell, it is a film about its own making. If we consider the contemporary period, some of the most outstanding Spanish shorts of the 1990s and early twenty-first century have a similar reflexive note of parody of Hollywood genres. This is the case, for example, with Mirindas asesinas (Álex de la Iglesia), Perturbado / Disturbed (Santiago Segura, 1993), and 7:35 a.m. - the last of these being a reflexive, hypertextual parody of the musical.

The marginal condition of Spanish cinema in the transnational market has from early on been a factor in these parodic retakes on genre cinema. This is evident in short fiction films, which, being made at the far edge of the industry's margins, are especially prone to plotlines that reflect on their own forms and limits. However, conditions of production alone do not explain the existence of shorts such as Vicente Lluch's Documento secreto / Secret Document, a parody of the spy film with a female protagonist who travels to the French-Spanish border to realize a dangerous secret mission while her boyfriend stays at home. This sixteen-minute film was made in 1942, when the Franco regime had not yet started to disengage itself from the Axis powers. Reflexivity, then, is about the renewal of cultural forms.

There is, however, a kind of reflexivity that is not concerned with parody. This is the case with the previously mentioned documentary compilation film Canciones para después de una guerra, in which Martín Patino takes apart the historical memory of Francoism. A non-parodic mode of reflexivity characterized the whole of documentary production during the transition to democracy, as seen in El desencanto (1976), El asesino de Pedralbes / The Murder of Pedralbes (Gonzalo Herralde, 1978), Ocaña, retrat intermitent, Rocío (Fernando Ruiz Vergara, 1980), Animación en la sala de espera / Animation in the Waiting Room (Carlos Rodríguez Sanz and Manuel Coronado, 1981), and Cada ver es / Every Sight Is (Ángel García del Val, 1981; the title is a pun on the Spanish for "corpses"). A similar non-parodic form of reflexivity is found in Aute's Un perro llamado Dolor, which comprises seven reflections in animated form on a series of Spanish and non-Spanish visual artists - particularly Goya and including Velázquez and Buñuel - with the director appearing on screen in person. Several recent reflexive documentaries are similarly anything but parodic. Andrés Duque dedicated his first film Iván $Z$ (2003) to the figure of Iván Zulueta. Much more than a survey of Zulueta's life and work, Duque's film takes up the challenge of Zulueta's experimental project, adapting it to his own creative agenda. The result avoids imitation by offering a reflection on the forms of experimental documentary at the time of the film's production. Duque would use one of the phrases spoken by Zulueta in Iván $Z$ as the title of his No es la imagen sino el objeto / It's not the Image but the Object (2008), a performative film that takes further the circle of meditations woven around Zulueta's figure. Equally striking is Carlos García Alix's El honor de las injurias / The Honor of the Wronged (2007), which tells the story of the anarchist Felipe Sandoval by resemanticizing iconic shots in the history of international documentary production together with others from Spanish fiction film, generating a highly productive interaction between both visual traditions (see Figure 18.5). 


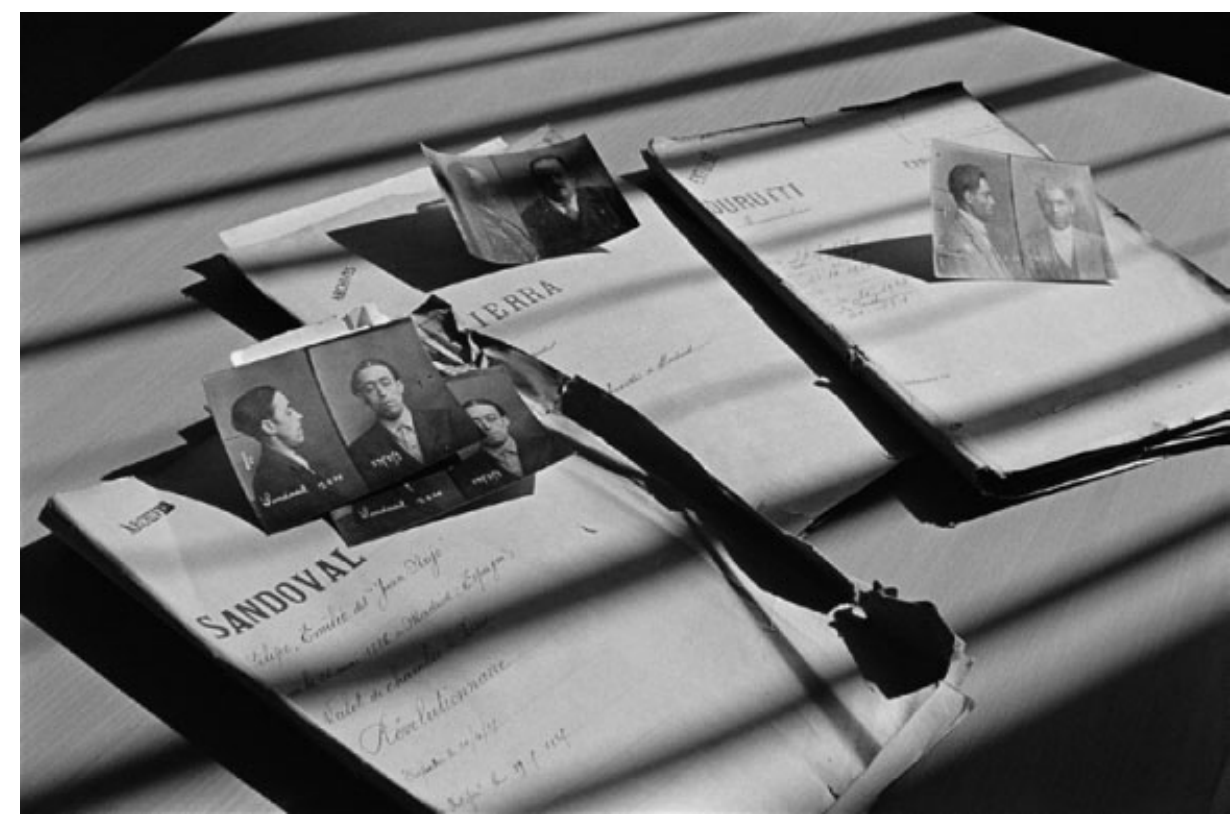

Figure 18.5 Shot in high-contrast black and white, El honor de las injurias (Carlos García Alix, 2007; prod. Andrea Santaolaya / No hay penas SL) undertakes a criminal investigation into the figure of the anarchist Felipe Sandoval. Courtesy of Andrea Santaolaya / No hay penas SL.

Consideration of Spanish documentary, animation, experimental film, and shorts in the light of the three conceptual categories proposed here goes some way toward giving a sense of their complexity, always bearing in mind the importance of chronology, which generic classifications so often ignore.

\section{References}

Alessandrini, L., Arbizzani, L., Bertrand de Muñoz, M., et al. (1999) Immagini nemiche: La Guerra civile spagnola e le sue rappresentazioni. Bologna: Editrice Compositori.

Cadé, M. (2010) La Retirada en images mouvantes. Canet: Trabucaire / Institut Jean Vigo.

Castro de Paz, J. L. and Cerdán, J. (2007) Tra(d)iciones y traslaciones del ensayo fílmico en España. In: Weinrichter, A. (ed.) La forma que piensa. Pamplona: Gobierno de Navarra, pp. 110-24.

Català, J. M., Cerdán, J., and Torreiro, C. (2001) Imagen, memoria y fascinación: Notas sobre el documental en España. Madrid: Ocho y Medio.

Elena, A. (2004) Romancero marroquí: El cine africanista durante la Guerra Civil. Madrid: Filmoteca Española.

Goebbels, J. (1937) “Die Wahrheit über Spanien.” Speech given at 1937 National Party Congress in Nüremberg. Berlín: Müller und Sohn. 
Gubern, R. (1986) 1936-1939. La guerra de España en la pantalla. Madrid: Filmoteca Española. Gubern, R. (1999) Proyector de luna: La generación del 27 y el cine. Barcelona: Anagrama.

Gubern, R. and Hammond, P. (2009) Los años rojos de Luis Buñuel. Madrid: Cátedra.

Kowalsky, D. (2003) La Unión Soviética y la guerra civil española: Una revisión crítica. Barcelona. Crítica.

Minguet Batllori, J. (2010) Segundo de Chomón: The Cinema of Fascination. Barcelona: Filmoteca de Catalunya.

Nicolás Meseguer, M. (2008) Las relaciones cinematográficas hispano-alemanas durante la guerra civil española y los inicios del franquismo (1936-1945). Unpublished $\mathrm{PhD}$ thesis. Universidad de Murcia: Departamento de Historia del Arte.

Pérez Perucha, J. (1993) La larga marcha. In: Llinás, F. (ed.) Directores de fotografía del cine español. Madrid: Filmoteca Española, pp. 22-55.

Ridruejo, D. (1976) Con fuego y con raices: Casi unas memorias. Barcelona: Planeta.

Romeiser, J. B. (1991) The Spanish Civil War and Fox Movietonews, 1936-1939. In: Vernon, K. (ed.) The Spanish Civil War and the Visual Arts. Ithaca: Cornell University Press, pp. 71-7.

Sala, R. (1993) El cine en la España republicana durante la guerra civil. Bilbao: Mensajero.

Sánchez-Biosca, V. (2006) Cine y guerra civil española: Del mito a la memoria. Madrid: Alianza.

Sánchez-Biosca, V. (ed.) (2008-9) Imágenes en migración: Íconos de la guerra civil española. Special double issue of Archivos de la Filmoteca 60-1.

Sontag, S. (2003) Regarding the Pain of Others. New York: Farrar, Straus and Giroux.

Stam, R. (1992) Reflexivity in Film and Literature: From Don Quixote to Jean-Luc Godard. New York: Columbia University Press.

Tranche, R. and Sánchez-Biosca, V. (2000) NO-DO: El tiempo y la memoria. Madrid: Cátedra / Filmoteca Española.

Tranche, R. and Sánchez-Biosca, V. (2011) El pasado es el destino: Propaganda y cine del bando nacional en la Guerra Civil. Madrid: Cátedra / Filmoteca Española.

Vicario, B. (1998) Breve historia del cine de animación experimental vasco. Madrid: Semana de Cine Experimental.

Vieira, J. L. (1982) From High Noon to Jaws: Carnival and Parody in Brazilian Cinema. In: Johnson, R. and Stam, R. (eds.) Brazilian Cinema. Cranbury: Associated University Presses, pp. 256-69.

\section{Further Reading}

Del Amo, A., with Ibáñez Ferradas, M. L. (1996) Catálogo general del cine de la Guerra Civil. Madrid: Filmoteca Española / Cátedra.

Fernández Cuenca, C. (1972) La guerra de España y el cine. Madrid: Editora Nacional.

Martínez Barrionuevo, M. L. (2003) El cine de animación en España (1908-2001). Madrid: Fancy Ediciones.

Medina, P., González, L. M., and Velázquez, J. M. (eds.) (1996) Historia del cortometraje español. Madrid: Festival de Cine de Alcalá de Henares. 


\section{Contents}

Acknowledgments viii

List of Figures $\quad$ ix

List of Contributors xviii

1 Introduction 1

Jo Labanyi and Tatjana Pavlović

$\begin{array}{lll}\text { Part I Reframing the National } & 13\end{array}$

2 Transnational Frameworks $\quad 15$

Gerard Dapena, Marvin D'Lugo, and Alberto Elena

Brad Epps

4 Negotiating the Local and the Global: Andalusia,

the Basque Country, and Galicia

José Colmeiro and Joseba Gabilondo

Part II The Construction of the Auteur

5 Auteurism and the Construction of the Canon 113 Marvin D'Lugo and Paul Julian Smith

6 Strategic Auteurism Antonio Lázaro-Reboll, Steven Marsh, Susan Martin-Márquez, and Santos Zunzunegui 
Part III Genre

7 Comedy and Musicals

Steven Marsh, Chris Perriam, Eva Woods Peiró, and Santos Zunzunegui

8 Melodrama and Historical Film

Jo Labanyi, Annabel Martín, and Vicente Rodríguez Ortega

Jo Labanyi, Antonio Lazaro-Reboll, and Vicente Rodriguez Ortega

\section{Part IV Stars as Cultural Icons}

10 The Construction of the Star System

Kathleen M. Vernon and Eva Woods Peiró

11 Stars, Modernity, and Celebrity Culture

Tatjana Pavlovic, Chris Perriam, and Nuria Triana Toribio

\section{Part V Image and Sound}

12 Photography, Production Design, and Editing

Vicente Sánchez-Biosca

13 Soundtrack

Romain Gubern and Kathleen M. Vernon

Part VI The Film Apparatus: Production, Infrastructure, and Audiences

14 Censorship, Film Studios, and Production Companies Josetxo Cerdán, Román Gubern, Jo Labanyi, Steven Marsh, Tatjana Pavlovic, and Nuria Triana Toribio

15 Film Clubs, Festivals, Archives, and Magazines Ferran Alberich, Román Gubern, and Vicente Sánchez-Biosca

16 Audiences Manuel Palacio and Kathleen M. Vernon

Part VII Relations with Other Media

17 Cinema, Popular Entertainment, Literature, and Television 
Part VIII Beyond the Fiction Film

18 Newsreels, Documentary, Experimental Film, Shorts, and Animation

Josetxo Cerdan and Vicente Sánchez-Biosca

\section{Part IX Reading Films through Theory}

19 Isabel Coixet's Engagement with Feminist Film Theory:

From $\mathrm{G}$ (the Gaze) to $\mathrm{H}$ (the Haptic)

Susan Martin-Márquez

20 Becoming a Queer (M)Other in/and/through Film:

Transsexuality, Trans-subjectivity, and Maternal

Relationality in Almodóvar's Todo sobre mi madre

Julian Daniel Gutiérrez-Albilla

21 The Space of the Vampire: Materiality and Disappearance in the Films of Iván Zulueta

Brad Epps

Index 